evidence that the owner of the herd has taken steps to eradicate tuberculosis from the herd and that, as a result of a tuberculin test made by a veterinary inspector of the Department concerned, the herd has been found to be free from tuberculosis. The present register comprises thirty-one herds in England and Wales, and twenty-seven herds in Scotland, attested up to August 31, and includes names and addresses, general description of breeds, and numbers in the herd. Further issues will be made from time to time, and copies may be obtained from the offices of the two departments at London and Edinburgh.

\section{Medical Services in the British Colonies}

THE fifth annual issue of the "Medical and Sanitary Reports from British Colonies, Protectorates and Dependencies for 1933" (Trop. Diseases Bull., 32, Sup. Nov. 1935. H. Harold Scott. 7s. 6d. net) gives an account of the activities of fifty-five medical services within the British Colonial Empire. Medical departments are making their contribution towards the general economic advancement of native com. munities by providing medical facilities for preventing and curing disease, and by developing health services and training for natives. The table of vital statistics appended is most useful, but shows the lack of reliable data for many parts of the Colonial Empire.

\section{Bibliography of Seismology}

We have received the last two numbers (for April-September 1935) of the Bibliography of Seismology compiled by Mr. E. A. Hodgson and issued by the Dominion Observatory of Ottawa (Publications, $12(1935))$. The number of memoirs included (234) is about the same as usual; but there is a tendency to omit abstracts except of those works that are not very accessible. One useful change is that lists are given of the notes on earthquakes and allied subjects that have appeared in NATuRe and in the Science News Letter (U.S.A.) and also of the articles in the Bulletin of the Seismological Society of America.

\section{Announcements}

M. RAMoN, assistant director of the Pasteur Institute, Paris, has been elected member of the French Veterinary Academy in the Section of Zootechnics and Animal Industry.

THe German Society of the History of Medicine, Science and Technology has elected Dr. Arthur Meiner, J. A. Barth, C. Kabitzsch, H. Meusser and L. Voss to honorary membership in recognition of their services to the history of science.

Tне British Chemical Plant Exhibition, organised by the British Chemical Plant Manufacturers' Association, will be held in the Central Hall, Westminster, London, S.W.1, on June 22-27. The Exhibition is boing arranged in connexion with the International Chemical Engineering Congress of the World Power Conference. A research exhibition is also being organised by the Department of Scientific and Industrial Research. Further information can be obtained from the Secretary, British Chemical Plant Manufacturers' Association, 166 Piccadilly, London, W.1.

THE following appointments have recently been made by the Secretary of State for the Colonies: W. Pulfrey to be assistant geologist, Kenya; $\mathrm{H}$. Service to be geologist, Gold Coast; J. A. Craig (principal agricultural officer, Kelantan) to be agricultural education and research officer, Department of Agriculture, Palestine; W. M. Robertson (senior assistant conservator of forests, Nigeria) to be conservator of forests, Sierra Leone; G. N. Sale (conservator of forests, Mauritius) to be conservator of forests, Palestine; N. W. Eades (superintendent of education) to be assistant field geologist, Tanganyika; A. F. Nichols (agricultural assistant, St. Lucia) to be assistant director of agriculture, Seychelles; L. H. Saunders (stockman, Veterinary Department, Nigeria) to be agricultural superintendent, Gambia.

Appurcations are invited for the following appointments, on or before the dates mentioned :

A principal of the Rochdale Municipal Technical School--The Education Secretary, Technical School, Rochdale (Jan. 21).

A mechanical engineer to the Safety in Mines Research Board-The Under-Secretary for Mines, Establishment Branch, Mines Department, Dean Stanley Street, Millbank, S.W.1 (Jan. 25).

Two lecturers in mechanical engineering in the Portsmouth Municipal College-The Registrar (Jan. 25).

A district lecturer in agriculture and an assistant lecturer in agricultural economics in the University of Leeds-The Registrar (Jan. 28).

An engineering assistant (III) at the Building Research Station, Garston-The Establishment Officer, Department of Scientific and Industrial Research, 16 Old Queen Street, Westminster, S.W.1 (Jan. 29).

A horticultural instructor for West Norfolk-The Horticultural Superintendent, 30 Cattle Market Street, Norwich (Jan. 31).

A teacher of electrical engineering and mathematics in the Watford Technical and Art Institute-The Principal (Jan. 31).

A junior assistant in the Library of the Science Museum, South Kensington, S.W.7-The Director (Feb. 1).

A director of antiquities in the Colonial Service, Cyprus-The Director of Recruitment (Colonial Service), 2 Richmond Terrace, Whitehall, London, S.W.1 (Feb. 15).

A professor of pathology in the University of Sydney--The Secretary of the Universities Bureau of the British Empire, 88A Gower Street, W.C.1 (April 15).

Examiners for the Aeronautical Inspection Directorate-The Secretary, S.2.D., Air Ministry, Adastral House, Kingsway, W.C.2. 